\title{
¿Cuál es su diagnóstico?
}

\author{
What should the diagnosis be?
}

Paciente varón, de 28 años de edad, que acude a nuestro Servicio, para estudio y tratamiento de tumoración láterocervical derecha de 4 años de evolución, dolorosa a la palpación y sin crecimiento progresivo. No tenía antecedentes médicos ni quirúrgicos.

A la exploración se apreciaba una masa laterocervical derecha, en zona cervical media, de $2,5 \mathrm{~cm}$ de diámetro mayor, de consistencia dura. Ésta estaba adherida al hueso hioides y se desplazaba con la deglución. No se palpaban adenopatías cervicales. El juicio clínico inicial fue de quiste tirogloso.

Se pidió una analítica, una ecografía, una Punción Aspiración con Aguja Fina (PAAF) y una Tomografía Computarizada (TC). En la analítica no se objetivaron alteraciones. El resultado de la ecografía fue de masa quística compatible con quiste tirogloso. En la TC se apreciaba una masa heterogénea (Fig.1). El diagnóstico de la PAAF fue: tumor mesenquimal.

Posteriormente, para descartar la existencia de tejido tiroideo ectópico, se realizó una gammagrafia, en la que no se evidenció un aumento de captación de radioisótopo por parte de la masa, ni alteraciones en la captación tiroidea.

Al mes de la primera consulta, con el diagnóstico de presunción de quiste tirogloso, se procedió a realizar la resección. Durante la disección de la masa, esta se rompió, vertiendo un contenido granuloso tumoral, del cual se realizó un estudio anatomopatológico intraoperatorio. El resultado fue: tumor maligno indiferenciado. Se procedió entonces a una resección del tumor con márgenes de seguridad, que incluían la musculatura peritumoral y la porción central del cuerpo hioideo.

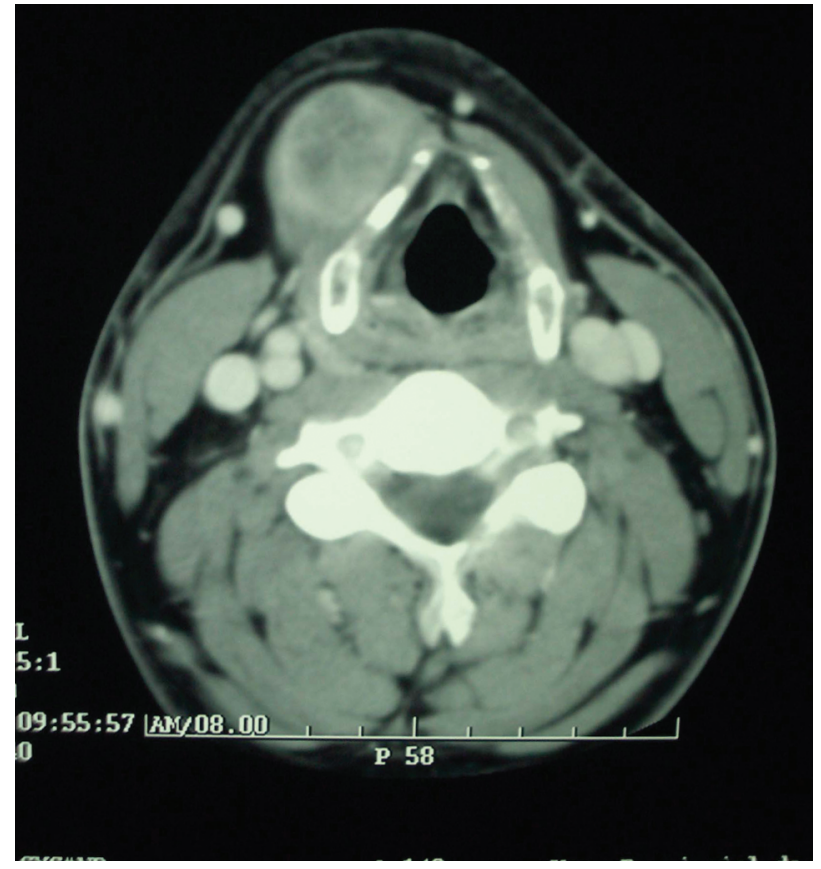

Figura 1. Imagen de TC, del tumor primario, donde se aprecia una masa cervical heterogénea.

Figure 1. CT image of the primary tumor showing a heterogeneous mass on the neck.

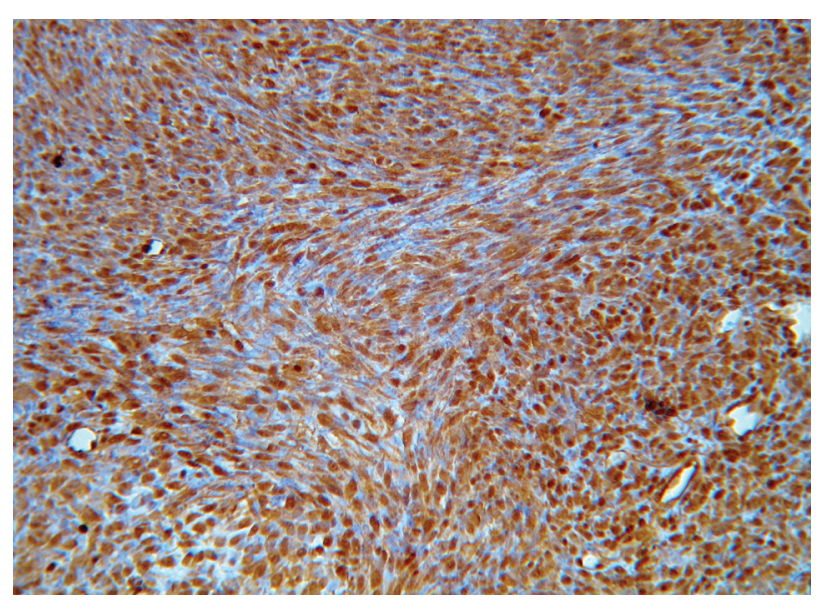

Figura 2. Inmunohistoquímica para Vimentina (X100): Importante positividad para Vimentina en sarcoma sinovial monofásico con patrón fusocelular típico.

Figure 2. Immunohistochemical results for vimentin (X100): Strongly positive for vimentin in monophasic synovial sarcoma with a typical spindle cell pattern.
Male patient, 28 years old, attended our Service, for an evaluation and treatment of a laterocervical tumor-like mass on the right side that had been evolving for four years. It was painful on palpation and did not exhibit progressive growth. He did not have any previous medical or surgical history.

On examination, a laterocervical mass could be appreciated on the right side, in the middle part of the neck, measuring $2.5 \mathrm{~cm}$ in greatest diameter, and which was hard in consistency. It was attached to the hyoid bone and moved on swallowing. Cervical adenopathies were not felt on palpation. The initial clinical opinion was of a thyroglossal cyst.

Blood tests, ultrasound, FineNeedle Aspiration Puncture (FNAP) and a Computerized Axial Tomography (CAT) scan were requested. The blood tests showed no irregularities. The result of the ultrasound showed a cystic mass, which was compatible with a thyroglossal cyst. The CAT scan showed a heterogeneous mass (Fig. 1). The diagnosis from the FNAP was of a: mesenchymal tumor.

Later, in order to eliminate the existence of any ectopic thyroid tissue, a gamma scan was carried out with radioisotope that did not 
Macroscopicamente al corte, se apreciaba una masa blanquecina, homogénea, con áreas parduzcas de aspecto hemático, identificándose un área calcificada y pétrea.

Los anatomopatólogos, tras realizar tinciones con hematoxilina eosina, informaron que se trataba de una neoformación densamente celular, con moderada atipia y alto índice mitósico. Presentaba un patrón sólido, fusocelular con áreas vasculares tipo hemangiopericitoma. La inmunohistoquimica fue positiva focalmente para citoqueratina; positiva para vimentina, intensamente, de forma difusa (Fig. 2); y negativa para S-100, actina, desmina, enolasa, cromogranina, y HMB45. show any increase in up-take in the area of the mass, nor any disturbances in thyroid up-take.

A month after the first consultation, with a presumed diagnosis of «thyroglossal cyst», a resection was carried out. During the dissection the mass ruptured, and the granular content of the tumor ran out, and this was used to carry out an intraoperative anatomopathologic study. The result was: undifferentiated malignant tumor. The resection of the tumor was then carried out leaving safety margins that included the muscle around the tumor and the central portion of the hyoid body.

Macroscopically the sections showed a whitish mass that was homogenous with brownish areas of a hematic appearance in which a calcified and lumpy area could be identified.

The anatomopathologists reported, following hematoxylin and eosin staining, that the mass consisted of a neoformation of densely packed cells, that was moderately atypical and that had a high mitotic index. It had a solid, fusocellular pattern with vascular areas of a hemangiopericytoma type. The immunohistochemical results were: focally positive for cytokeratin; diffusely strongly positive for vimentin (Fig. 2); and negative for S-100, actin, desmin, enolase, chromogranins, and HMB45. 


\title{
Sarcoma sinovial, monofásico fusocelular, cervical
}

\section{Monophasic spindle cell synovial sarcoma of the neck}

\author{
J.A. García de Marcos', A. Dean Ferrer', F. Alamillos Granados², \\ J.J. Ruiz Masera², G. Barrios Sánchez'1, A. Vidal Jiménez ${ }^{3}$
}

El diagnóstico fue Sarcoma sinovial monofásico fusocelular.

El paciente fue derivado entonces, a los servicios de Oncología Médica y de Oncología Radioterapeútica, recibiendo un tratamiento quimioterápico adyuvante con Epirubicina e Ifosfamida, cada 21 días, un total de 6 ciclos. Posteriormente recibió tratamiento de radioterapia cervical de 66 Gy.

Dos años y tres meses después de la primera cirugía el paciente presenta un nuevo nódulo localizado a nivel parahioideo izquierdo de crecimiento progresivo (Fig. 3). Tras realizar una TAC, se aprecia una masa sólida, heterogénea de $5,5 \mathrm{~cm}$ de diámetro mayor, situada entre el cartílago tiroides, músculo esternocleidomastoideo y glándula tiroides del lado izquierdo del cuello (Fig. 4). No se evidencian otras lesiones a nivel cervical, ni hallazgos en pulmones y mediastino. El paciente se reinterviene realizándose una resección de la tumoración incluyendo musculatura prelaríngea y el músculo omohioideo (Fig. 5). El diagnóstico anatomopatológico de la pieza fue: sarcoma poco diferenciado compatible con sarcoma sinovial.

El paciente vuelve a ser tratado por parte del servicio de Oncología Médica, administrándosele quimioterapia adyuvante, que consistió en cuatro ciclos con igual esquema que el anterior, hasta agotar la dosis de Antraciclinas.

\footnotetext{
1 Médico Residente, Cirugía Oral y Maxilofacial.

2 Especialista en Cirugía Oral y Maxilofacial.

3 Médico Residente, Anatomía Patológica.

Servicio de Anatomía Patológica.

Hospital Universitario «Reina Sofía». Córdoba, España.
}

\author{
Correspondencia: \\ J.A. García de Marcos \\ C/ Antonio Acuña, 10, 5ㅇizq \\ 28009 Madrid, España. \\ E-mail: pepio2@hotmail.com
}

The diagnosis was of monophasic spindle cell synovial sarcoma.

The patient was then referred to the Medical Oncology and Radiotherapeutic Oncology Services where he was given adjuvant chemotherapy treatment with epirubicine and ifosfamide every three weeks and for six cycles. He later received radiotherapy treatment to the neck of $66 \mathrm{~Gy}$. Two years and three months after the first surgery, the patient presented with a new nodule that was located at the level of the parahyoid bone on the left side, and which was growing progressively (Fig. 3). After carrying out a CT scan, a solid mass could be seen that was heterogeneous and that measured $5 \times 5 \mathrm{~cm}$ in greatest diameter. It was situated between the thyroid cartilage, the sternocleidomastoid muscle and the thyroid gland on the left side of the neck (Fig. 4). No other lesions were found around the neck or lungs or in the mediastinum. The patient was reoperated and an excision was carried out of the tumor that included the prelaryngeal muscle group and the omohyoid muscle (Fig. 5). The anatomopathologic diagnosis of the sample was of: poorly differentiated sarcoma compatible with synovial sarcoma.

The Medical Oncology Service treated the patient again and he was given adjuvant chemotherapy, which consisted of four cycles with a similar regimen as the previous one, until completing the dose of antracycline.

During a CAT scan check of the neck and lungs, two nodules appeared in the lungs. These were removed 10 months after the second surgery. The anatomopathological result was of lung metastasis of poorly differentiated sarcoma, compatible with monophasic synovial sarcoma.

$A$ year and a half after the first local relapse the patient had a new cervical relapse. In the CAT scan a mass on the left side of the neck could be appreciated that was in contact with the infrahyoid muscles and with the plates of the thyroid cartilage on this side (Fig. 6). Surgical intervention was carried out and the lesion, the adjacent muscles and the left half of the hyoid bone were resected. The tumor was released from the left side of the thyroid cartilage, and a 
En una TC cervicotorácica de control se apreciaron dos nódulos pulmonares. Estos fueron resecados 10 meses después de la segunda cirugía. El resultado anatomopatológico fue metástasis pulmonar de sarcoma poco diferenciado, compatible con sarcoma sinovial monofásico.

Año y medio después de la primera recidiva local el paciente presenta nueva recidiva cervical. En la TC se aprecia una masa cervical izquierda en contacto con la musculatura infrahioidea y con la lámina del cartílago tiroides de ese lado (Fig. 6). Se realizó una intervención quirúrgica resecando la lesión, la musculatura adyacente y el hemihiodes izquierdo. Se despegó el tumor del lado izquierdo del cartílago tiroides, realizando una condrectomía periférica de cartílago tiroides. El resultado histopatológico fue: sarcoma sinovial monofásico. Posteriormente se le administraron tres ciclos de quimioterapia con Etopóxido más Ifosfamida. En un año de evolución, después de la ultima cirugía, no hemos encontrado signos de recidiva.

\section{Discusión}

El sarcoma sinovial constituye de un 3-10\% de todos los sarcomas. Generalmente afecta a adultos jóvenes, dos tercios de los cuales tienen menos de 40 años. Los hombres se afectan más frecuentemente que las mujeres con porcentajes de 2:1 ó 3:2.1,2

A pesar de su nombre estos tumores no se originan a partir del tejido sinovial, sino que proceden de células mesenquimales pluripotenciales situadas tanto cerca como lejos de las superficies articulares. ${ }^{3}$ Debido a esto; éste tipo de tumor raramente aparece en membranas sinoviales, unicamente un $10 \%$ afecta espacios articulares. Más a menudo se encuentra en la vecindad de grandes articulaciones y bolsas, dentro o cerca de los tendones y de las vainas tendinosas y en fascias aponeuróticas. ${ }^{2,4}$

En un $75 \%$ a un $95 \%$ de las ocasiones el sarcoma sinovial se localiza en las extremidades, siendo más frecuente la afectación en las inferiores. Los sitios más comunes de origen son alrededor de la articulación de la cadera, rodilla, tobillo, hombro y muñecas. Además, puede aparecer en la pelvis, en cabeza y cuello, y en áreas desprovistas de tejido sinovial, como la pared abdominal. ${ }^{2}$

Entre un 3 y un $10 \%$ de los sarcomas sinoviales aparecen en cabe-

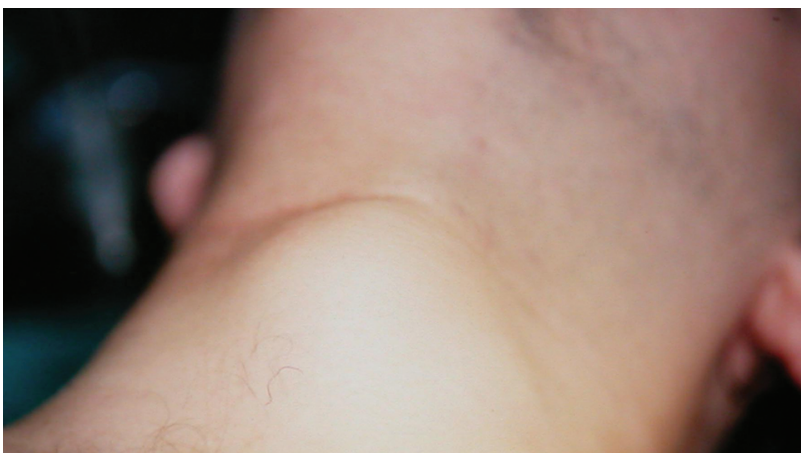

peripheral chondrectomy of thyroid cartilage was performed. The histopathological result was of: monophasic synovial sarcoma. He was later given three cycles of chemotherapy with etoposide and ifosfamide. In the year following the last intervention there have been no signs of relapse.

\section{Discussion}

Synovial Sarcomas account for $3-10 \%$ of all sarcomas. Generally young adults are affected, two thirds of whom are under the age of 40 . Men are more frequently affected than women with a 2:1 or 3:1 rate. ${ }^{1,2}$

In spite of its name, these tumors do not originate from synovial tissue, rather they arise from pluripotential mesenchymal cells situated by, as well as away from, joint surfaces. ${ }^{3}$ As a result, this type of tumor rarely appears in synovial membranes with only $10 \%$ affecting joint spaces. It is found more often in the area of large joints and sacs, in or near tendons and tendon sheaths, and fascial aponeuroses. 2,4

In 75 to $95 \%$ of occasions synovial sarcomas are located in the extremities with the lower extremities being more frequently involved. The most common sites of origin are around the hip, knee, ankle, shoulder and wrist joints. It may also appear in the pelvis, the head and the neck, and in areas that do not have synovial tissue such as the abdominal wall. ${ }^{2}$

Between 3 and $10 \%$ of synovial sarcomas appear in the head and neck.2,4,5 Jernstrom described the first case with this location in 1954 and it entailed a hypopharyngeal tumor. ${ }^{1,4}$

Patients with synovial sarcomas of head and neck have a mean age of 25 to 30 and the age range is 7 to 63 years. Gender distribution is the same as in the rest of the economy. ${ }^{1}$ 
za y cuello. 2,4,5 El primer caso en esta localización, fue descrito, en 1954, por Jernstrom, y se trataba de un tumor de hipofaringe. ${ }^{1,4}$

Los pacientes con sarcomas sinoviales en cabeza y cuello, tienen una media de 25 a 30 años de edad con un rango de 7 a 63 años. Y la distribución por sexos es igual que en el resto de la economía. ${ }^{1}$

En cabeza y cuello la hipofaringe es la zona más frecuentemente afectada. Otras localizaciones, en cabeza y cuello, descritas en la literatura son el espacio parafaringeo, cavidad oral, lengua, parótida, articulación temporomandibular, región nasosinusal, nasofaringe, orofaringe, etc. Aunque virtualmente cualquier área puede afectarse. ${ }^{1-4}$

El tamaño de estos tumores puede variar en el momento del diagnóstico entre 1 y $12 \mathrm{~cm}$, con una media de 5 $\mathrm{cm} .{ }^{1}$ Generalmente se trata de tumores solitarios y firmes, con superficies de corte suaves y brillantes, bien circunscritos, esféricos o micronodulares, con pseudocápsula y de color amarillo grisáceo reluciente.1,6 Frecuentemente existe calcificación focal y puede tener focos quísticos o hemorrágicos (como en el caso aportado por nosotros). ${ }^{1}$

Aunque la mayoría de las metástasis son por vía sanguínea, de un 10 a un $20 \%$ de lo pacientes tienen metástasis linfáticas. Las metástasis pulmonares ocurren generalmente en los dos primeros años tras el diagnóstico del primario. ${ }^{6}$

Clínicamente, los sarcomas sinoviales de cabeza y cuello suelen aparecer como una masa de crecimiento lento y no dolorosa. Solo en un $20 \%$ de los casos aparece dolor.1,6 Generalmente suele producir disnea, disfagia y ronquera por la presión del tumor en la hipofaringe y la laringe. La mayoría de pacientes buscan la atención médica dentro del primer año, desde el inicio de sus síntomas.

La mayoría de los sarcomas sinoviales pueden parecerse clínicamente a un fibrosarcoma o a un rabdiomiosarcoma, por comportarse como una masa que infiltra tejidos blandos. ${ }^{2}$

El diagnóstico diferencial hay que hacerlo con las masas cervicales y como se trata de un paciente joven habrá que pensar en el quiste tirogloso, quistes de las hendiduras branquiales, adenopatías específicas (tuberculosis, sarcoidosis, etc.), o bien tumores de origen mesenquimal, tumores de origen en glandulas salivales, metástasis ganglionares y linfomas.

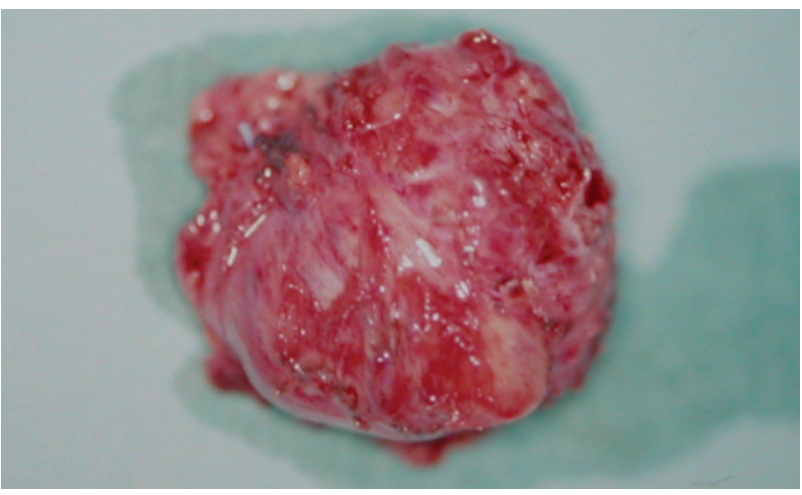

Figura 5. Aspecto macroscópico de la masa (primera recidiva) tras su extirpación quirúrgica.

Figure 5. Macroscopical appearance of the mass (first recurrence) following surgical removal.

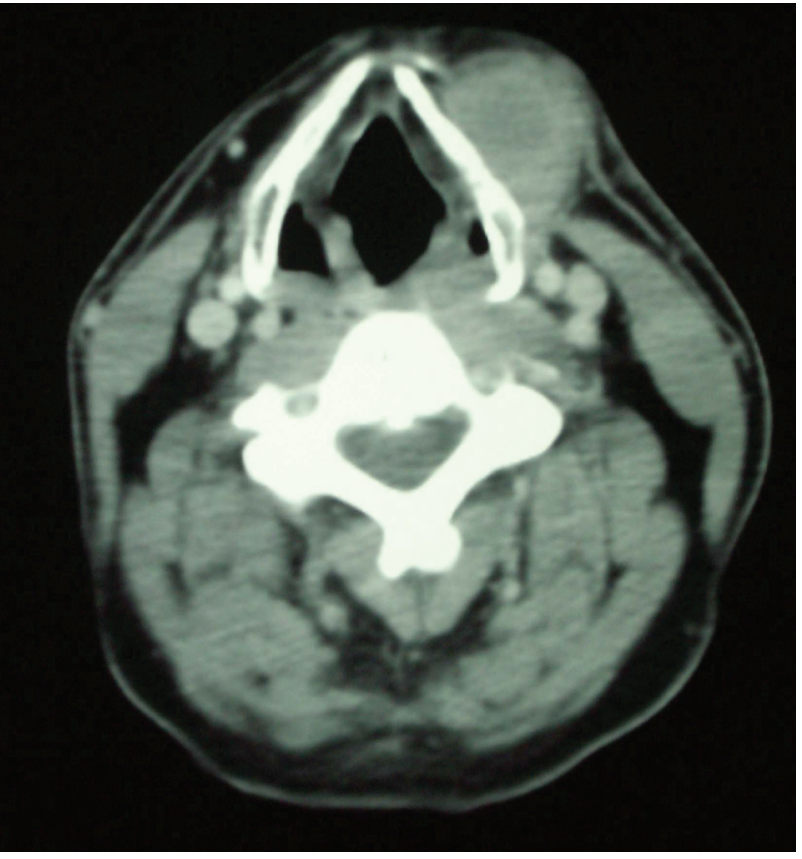

Figura 6. Imagen de TC, de la segunda recidiva, donde se aprecia una masa sobre el cartílago tiroides.

Figure 6. CT scan image, at second relapse, showing a mass over the cartilage of the thyroid.
In the head and neck it is the hypopharynx that is the area most affected. Other locations of the head and neck that have been described in the literature include the parapharyngeal space, oral cavity, tongue, parotid gland, temporomandibular joint, the area of the nasal sinuses, nasopharynx and oropharynx, etc. although virtually any area may be affected. ${ }^{1-4}$

The size of these tumors can vary when diagnosed from 1 to $12 \mathrm{~cm}$, the mean size being $5 \mathrm{~cm} .^{1}$ Generally these are firm, solitary tumors with a shiny cut surface, well-circumscribed, either spherical or micronodular with a pseudocapsule and a yellowish-gray shiny color. There is frequently focal calcification and there can be cystic or hemorrhaging areas (such as in the case we present).

Although metastasis largely takes place through the blood stream, 10 to 20\% of patients develop lymphatic metastasis. Lung metastasis occurs generally during the first two years following the diagnosis of the primary tumor. ${ }^{6}$

Clinically, synovial sarcomas of the head and neck tend to appear as slow-growing painless masses. Only in 20\% of cases does pain appear. ${ }^{1,6}$ Generally dyspnea, dysphagia and hoarseness arise due to the pressure of the tumor on the hypopharynx and larynx. Most patients seek medical attention during the first year, at the onset of symptoms.

Most synovial sarcomas can appear clinically to be a fibrosarcoma or a rhabdomyosarcoma, as they behave as a mass that infiltrates soft-tissues. ${ }^{2}$

A differential diagnosis has to given with neck masses and, as young patients are involved, thyroglossal cysts, branchial cleft cysts and specific adenopathies (tuberculosis, sarcoidosis, etc.) have to be considered, and also tumors 
Tanto en la TC como en la Resonancia Magnética Nuclear (RM) se describe la lesión, en cabeza y cuello, generalmente bien delimitada, sólida, y en ocasiones con un componente hemorrágico o quístico, así como con calcificaciones. ${ }^{2-4}$ Las imágenes tanto de TC como de RM, deben incluir el cuello entero, porque un $12,5 \%$ de los pacientes con sarcoma sinovial en cabeza y cuello, tienen afectación nodular linfática regional.4,6 Además, se debe realizar una TC torácica, para detectar la existencia de metástasis pulmonares, que son causa de muerte en un número significativo de pacientes. ${ }^{6}$ Los sarcomas sinoviales histológicamente se caracterizan por la presencia de un patrón bifásico que consiste en un fondo estromal compuesto por células fusiformes con apariencia similar a fibroblastos, firmemente compactados, y con un aspecto relativamente monótono. Sobre este fondo se dispone el componente epitelial, habitualmente como formaciones glandulares, nidos compactos, o espacios con hendiduras. ${ }^{7}$ Las áreas fusocelulares recuerdan a la histología del fibrosarcoma. ${ }^{1,2}$ Los sarcomas sinoviales pueden ser muy vasculares pudiendo similar histológicamente a un hemangiopericitoma. La proporción relativa entre células fusiformes y células epiteliales varía entre caso y caso y dentro de la misma lesión.

Existen formas monofásicas de sarcoma sinovial, que presentan únicamente un patrón histológico fusocelular o epitelial,1,4 Las metástasis de las formas bifásicas pueden tener un patrón monofásico o bifásico, mientras que las metástasis de las formas monofásicas son siempre monofásicas. ${ }^{1}$

Se han realizado estudios citogenéticos del sarcoma sinovial, en los que se ha demostrado una traslocación recíproca específica en el cromosoma X y 18 en más del $90 \%$ de los casos. Tanto bifásicos como monofásicos (p11,2; q11,2). 1,2,4,7 La mayoría de los casos de sarcoma sinovial son diploides.

Las técnicas inmunohistológicas han demostrado que las células fusiformes, y de manera menos frecuente las células epiteliales, se marcan con vimentina, que es un marcador mesenquimal. La reactividad a citoqueratina y a antígeno de membrana epitelial se encuentra no sólo en los patrones con componente epitelial, sino también, en un pequeño porcentaje de las células, en los patrones monofásicos de células fusiformes. Algunos sarcomas sinoviales expresan proteina S-100.1,7

El tratamiento para el sarcoma sinovial es quirúrgico. ${ }^{1}$ Se debe realizar una resección con márgenes de seguridad, a menudo incluyendo los tejidos adyacentes, como la musculatura peritumoral. ${ }^{4}$ No se considera necesaria la realización rutinaria de una disección radical de cuello si no existen adenopatías. ${ }^{1}$ La tasa de recurrencia de los sarcomas sinoviales en cabeza y cuello, después de una escisión local, varía entre el $21 \%$ y el $56 \%$, por lo que está indicada la radioterapia postoperatoria. ${ }^{1,4,6}$ La quimioterapia adyuvante puede reducir o retrasar la aparición de metástasis a distancia. ${ }^{1,4}$

Generalmente los sarcomas tienen una evolución prolongada, pudiendo desarrollar metástasis en algunos pacientes hasta 20 años después de la terapia inicial. La media de supervivencia es aproximadamente de 5 a 6 años, siendo posibles largos periodos de supervivencia, incluso con la existencia de metástasis. La supervivencia del sarcoma sinovial de cabeza y cuello, a los 5 años es del $36 \%$ al $54 \%$, y a los 10 años es del 20\%, debida a la aparición de metástasis. ${ }^{1,4}$ of mesenchymal origin, those originating in the salivary glands, lymph node metastasis and lymphomas.

In CAT and the Nuclear Magnetic Resonance (NMR) imaging, the lesion is described in the head and neck as generally being well-defined, solid, and on occasions as having a hemorrhagic or cystic component as well as calcifications. ${ }^{2-4}$ The images from the CAT scan as well as from the NMR should include all the neck, because in $12.5 \%$ of patients with synovial sarcoma of the head and neck there is regional lymph node involvement. ${ }^{4,6}$ A CAT scan of the thorax should also be carried out in order to detect the existence of lung metastasis, which is the cause of death in a significant number of patients. ${ }^{6}$ Synovial sarcomas are histologically characterized by the presence of a biphasic pattern consisting of a stromal background made up of spindle cells that appear to be tightly compacted fibroblasts with a relatively monotonous appearance. The epithelial component is set out against this background usually exhibiting a glandular formation, compact nests, or cleft-like spaces.7 The fusocellular areas remind one of the histology of the fibrosarcoma..$^{1,2}$ These synovial sarcomas can be highly vascular and they may appear histologically as hemangiopericytomas. The relative proportion of spindle cells to epithelial cells varies from case to case and within the lesion itself.

There are monophasic forms of synovial sarcoma that only have a fusocellular or epithelial histological pattern.1,4 Metastasis of the biphasic type can have a monophasic or biphasic pattern, while metastasis of the monophasic type is always monophasic. ${ }^{1}$

Cytogenetic studies have been carried out of synovial sarcomas that have shown a reciprocal translocation between chromosome $X$ and 18 in more than $90 \%$ of cases, in biphasic as well as monophasic cases (p11.2; 111.2$)^{1,2,4,7}$ Most cases of synovial sarcoma are diploid. ${ }^{1}$

Immunohistological techniques have demonstrated that spindle cells, and epithelial cells to a lesser degree, are stained by vimentin, which is a mesenchymal marker. The reactivity to cytokeratin and to epthithelial membrane antigen is not only found in patterns with an epithelial component but also in a small percentage of cells, in the monophasic patterns of spindle cells. Some synovial sarcomas express S-100 protein. 1,7

The treatment for synovial sarcoma is surgical. ${ }^{1}$ Excision with security margins should be carried out, and should often include adjacent tissue, such as the muscles around the tumor. ${ }^{4}$ Routine radical dissection of the neck is not considered necessary if there are no adenopathies. 1 The recurrence rate of synovial sarcomas of the head and neck, after local excision, varies between 21 and 56\%, and postoperative radiotherapy is therefore indicated. $1,4,6$ Adjuvant chemotherapy can reduce or delay the appearance of distant metastasis. ${ }^{1,4}$

Generally sarcomas have a prolonged evolution, and metastasis can develop in some patients up to 20 years after the initial therapy. The average survival rate is approximately 
El pronóstico del sarcoma sinovial viene determinado por una serie de factores: histológicamente, los sarcomas sinoviales calcificantes tienen mejor pronóstico que el resto; ${ }^{1,4}$ según su diámetro mayor y la extensión, los tumores menores de $5 \mathrm{~cm}$ y que no invaden estructuras adyacentes tienen un mejor pronóstico; según la localización, en cabeza y cuello tienen mejor pronóstico que en extremidades, ${ }^{4}$ siendo la lengua la localización con mejor pronóstico; ${ }^{1}$ según el índice del Ki-67, cuando este es mayor al 10\%, existe un peor pronóstico. ${ }^{5}$

\section{Bibliografía}

1. Kiriakos M, El-Mofty S. Pathology of selected soft-tissue tumors of the head and neck. En: Thawley SE, Panje WR, Batsakis JG, Lindberg RD. Comprehensive Management of Head and Neck Tumors. $2^{\underline{a}}$ Ed. Philadelphia. W.B.Saunders Company 1999;Cap. 63. pp.1349-51.

2. Malignant Soft Tissue Tumors of Mesenchimal Origin. En: Marx RE, Stern D. Oral and Maxillofacial Pathology. A Rationale for Diagnosis and Treatment. Illinois. Quintessence Publishing Co, Inc 2003; Cap. 10. pp.495-6.

3. Park JK, Ham SY, Hwang JC, Jeong YK, Lee JH, Yang SO, Suh JH, Choi DH. Synovial sarcoma of the head and neck: A case of predominantly cystic mass. Am J Neuroradiol 2004;25:1103-5.

4. Rangheard AS, Vanel D, Viala J, Schwaab G, Casiraghi O, Sigal R. Synovial sarcomas of the head and neck: CT and MR imaging findings of eight patients. Am J Neuroradiol 2001;22:851-7.

5. Bilgic B, Mete O, Öztürk AS, Demiryont M, Keles N, Basaran M. Synovial sarcoma: a rare tumor of larynx. Pathol Oncol Res 2003; 9: 242-5.

6. Cotton RT, Rothschild MA, Zwendling T, Ballard ET, Myer CM, Koch B. Tumors of the head and neck in children. En: Thawley SE, Panje WR, Batsakis JG, Lindberg RD. Comprehensive management of head and neck tumors. $2^{-a}$ Ed. Philadelphia. W.B.Saunders Company 1999; Cap 81. pp.1857-8.

7. Rosai J. Soft Tissues. En: Juan Rosai. Rosai and Ackerman's Surgical Pathology. 9a Ed. China. Mosby 2004; Cap 25. pp.2309-13.
5 to 6 years, with long periods of survival being possible, even when metastasis exists. The survival rate for synovial sarcoma of the head and neck at five years is 36 to $54 \%$ and at 10 years it is $20 \%$ due to the appearance of metastatis. 1,4

The prognosis of synovial sarcoma is determined by a series of factors: histologically calcified synovial sarcoma carry a better prognosis than the rest $; ;^{1,4}$ depending its greatest diameter and extension, tumors measuring less than $5 \mathrm{~cm}$ that are not invading adjacent structures carry a better prognosis; according to the location, the prognosis in the head and neck is better than in the extremities, ${ }^{4}$ with the tongue carrying the best prognosis; ' according to the Ki-67 index, when this is greater than $10 \%$ the prognosis is worse. 5 